\title{
ANALYSIS OF VOLLEYBALL ACHIEVEMENTS OF POPDA MEN'S VOLLEYBALL EAST OKU REGENCY
}

\author{
Fery Ardianto ${ }^{1}$, Meiriza Usra ${ }^{2}$, Rostika Flora ${ }^{3}$, Iyakrus ${ }^{4}$ \\ Universitas Sriwijaya, Indonesia ${ }^{1,2,3,4}$ \\ feryardianto1286@gmail.com¹, meirizalusra@fkip.unsri.ac.id², rostikaflora@gmail.com³, \\ iyakrus@fkip.unsri.ac.id ${ }^{4}$
}

\begin{abstract}
The background of this research is due to the volley ball is the sports featured East OKU regency, however lately achievements of volleyball East OKU regency decreased in POPDA. Coaching volleyball is important to do, because it can affect the development of the sport. Sports coaching volleyball cannot be done instantaneously, but rather through a variety of processes and stages in a current period of time. Some of the components of coaching sport achievements, are: (1) Financial Support, (2) the Organization and structure of the policy of unified sports, (3) Foundation and participation, (4) Identification and development of talent, (5) Fostering the achievements of an elite group or system of rewards and support on the after career, (6) sports Infrastructure or training facilities, (7) the Provision of a coach, the coaching and the quality of training, (8). The quality of competition, (9). Scientific research, and (10). Environmental media and sponsorship. The method used in this research is the qualitative and quantitative descriptive. The analysis Model used is the model logic. Model logic can not be described, namely the Planned work consisting of input and activities, as well as the Intended results consisting of the Outputs, outcomes and Impact. By using logic is expected to get optimal results in analyzing the coaching achievements of volleyball POPDA East OKU regency. Techniques in the collection of research data are observations, interviews and questionnaires. The result of the analysis of volleyball achievement coaching POPDA East OKU regency is $57.59 \%$ with enough categories. With input variable details get a percentage of $68.99 \%$, Activities variables get a percentage of $66.77 \%$, Output variables get a percentage of $46.96 \%$, Outcome variables get a percentage of $53.91 \%$ and Impact variables get a percentage of $51.30 \%$.
\end{abstract}

Keywords: Coaching, achievements, volleyball, POPDA

Accepted: 9th of July 2021
$\begin{aligned} & \text { Correspondence author: Fery Ardianto, Universitas Sriwijaya, Indonesia. E-Mail: } \\ & \text { feryardianto1286@gmail.com } \\ & \text { DOI http://dx.doi.org/10.31851/hon.v4i2.5907 doi }\end{aligned}$




\section{OLATRAGA

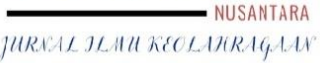

Jendral A. Yani Street Lorong Gotong Royong 9/10 U1u

Palembang South Sumatera

Accredited

email jurnal: jurnalhon@univpgri-palembang.ac.id situs web: http://www.univpgri-palembang.ac.id

\section{INTRODUCTION}

Sports coaching and development needs to be continuously improved in a directed, systematic, and sustainable manner in order to align with national development goals, especially in improving the welfare of the people (Mutohir and Maksum, 2007). Meanwhile according to (Lutan, 2013) there are ten components of sports coaching achievements, they are (1) Financial Support, (2) Organization and structure of integrated sports policy, (3) Education and breeding, (4) Identification and development of talent, (5) Coaching the achievements of elite groups or reward systems and support in the post-career period, (6) Sports infrastructure or training facilities, (7) Provision of a coach, coaching and quality of training, (8). Quality of competition, (9). Scientific research, and (10). Media and sponsorship environment.

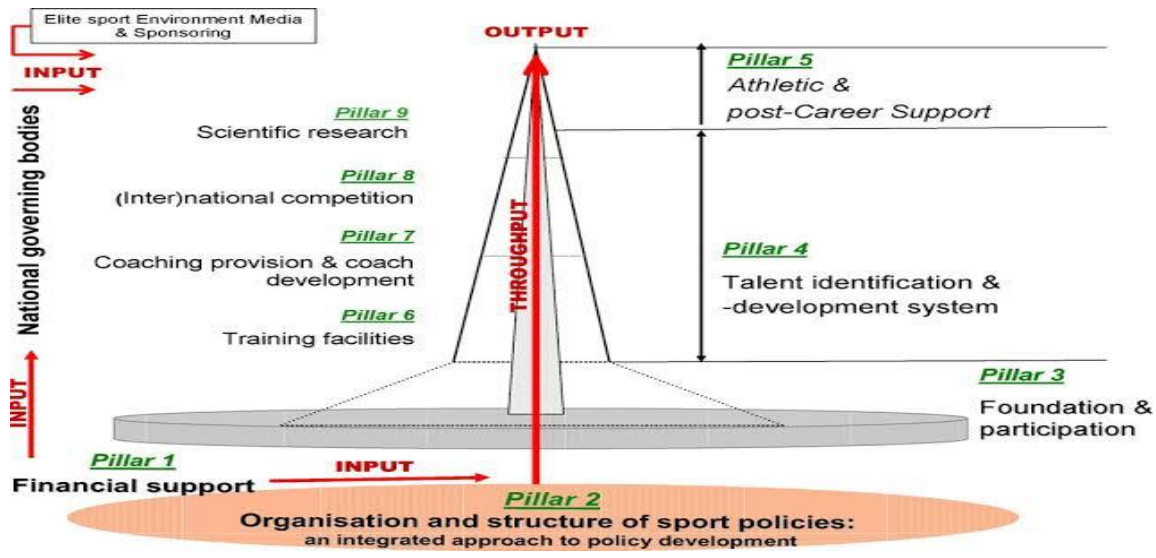

Figure 1. Pillars in the achievement sports coaching system (Lutan, 2013)

A coaching process that is systematic and continuous analysis is required for a sport so obtained the appropriate formula to be able to realize the maximum performance of a sport (Arisman \& Noviarini, 2021). The implementation of the analysis aims to find the real facts in the real life that the each other and their respective functions in an integrated. In line with result can be positive or negative (Okilanda et al., 2018).

According to (Komaruddin, 2001) Analysis is the activity of thinking to decipher a whole into components so that it can recognize the signs of the 
components, their relation to the above opinion according to (Wiradi, 2009) analysis or analysis is the activity that contains a number of activities such as parse, choose something to classified or grouped according to certain criteria then interpreted and in search of its meaning. From the definition above it can be concluded the analysis is to decipher a whole into component parts and then grouped according to the criteria and then said with argument. Analysis activities can be done using logical models (Putra et al., 2020). "Logical model is a logical and precise depiction of the program according to certain conditions in order to solve problems. In general, the shape of depiction using a flow diagram that describes the activities planned (Planned Work) and expected Results (Intended Results) of the model evaluation (Kellogg Foundation, 2004). (Kellogg Foundation, 2004) explains that the: "basically, a logic model is a systematic and visual way to present and share your under standing of the relationships among the resources you have to operate program, the activities you plan, and the changes or results you hope to achieve (Ardo Okilanda, Firmansyah Dlis, Hidayat Humaid, 2020). " The peculiarities of the logical model is the use of tables and graphs flow that contains the input, activity, and results. Most of the use of text and arrows or chart to illustrate the sequence of activities to produce change, and how these activities are connected with the results of the program is reached. It takes the right decision before using the model logic (Kellogg Foundation, 2004), because the preparation of the model logic is complex and involves one of the three approaches, namely: model approach (conceptual), outcomes approach, and activity approach (applied) or is a mixture of some of the above types (Okilanda, 2017). Logical model can be described as Planned work consisting of inputs and activities, and Intended results consisting of Outputs, outcomes and Impact. (Kellogg Foundation, 2004) 
HALAMAN OLAHRAGA Palembang South Sumatera
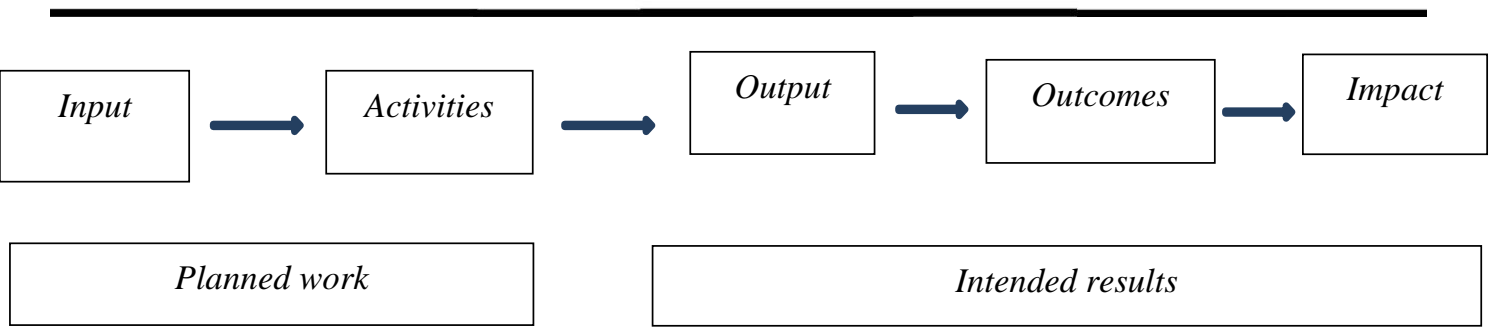

\section{Intended results}

Figure 2. Logical Model (Will Keith Kellogg Foundation, 2004)

One of the achievement coaching programs in the field of sports East OKU regency is volleyball. KONI East OKU regency classifies sports into three, they are : 1) The flagship sports branch consisting of: Athletics, wushu, gymnastics and Volleyball, 2) Potential Sports consisting of: Martial Art, karate, tae kwon do, sepak takraw, archery, shooting, and chess. 3) Sports coaching consisting of: Football, table tennis, basketball, handball, swimming and badminton. (Interview of General Secretary of KONI East OKU regency. 2020). Lately there has been a decrease in achievements in the sports coaching that is a superior branch of the sport of volleyball, it can be seen from the results of the championship POPDA mens team volleyball East OKU regency as follows: in 2006, 2008 and 2010 can be achieved gold medalist, the 2012 silver medalist, in the year 2014 and 2016 decreased again, just get the medal and bronze (the interview the Chairman of the PENGKAB PBVSI East OKU regency: 2020) .

Volleyball in East OKU is one of the sports featured KONI East OKU district. so it is a pity when POPDA's achievements decrease because it will result in the coaching of volleyball at higher championship levels such as PORPROV, PraPON and so on because of this POPDA competition will be born talented volleyball players in East OKU. So the researchers are interested to evaluate the program coaching achievements volleyball POPDA East OKU.

\section{METHOD}

The method used two approaches in this research is the qualitative and quantitative descriptive. The approach used in this research-oriented goals that are directed to measure the level of achievement of the implementation of the 
program (Taufik et al., 2021). This study uses a logical model. In particular, this study is to: (1) Know the dimensions of inputs, about the acceptance system of players and coaches, facilities and infrastructure and financing that support the achievements of volleyball POPDA East OKU. (2) Knowing the dimensions of activities, concerning the implementation of achievement coaching system, achievements, training program system, supervision of program implementation, welfare of players, coaches, and administrators, coaching program POPDA volleyball achievements East OKU. (3) Knowing the dimensions of the output regarding, the success of the coaching achievements of volleyball POPDA East OKU. (4) Knowing the dimensions of the outcome concerning, the benefits of coaching the achievements of volleyball POPDA East OKU. (5) Knowing the dimensions of impact regarding, the influence of coaching the achievements of volleyball men POPDA East OKU. coaches understand the needs in practising various conditions (Okilanda et al., 2021).

The subjects of this study are all elements that affect the development of the achievements of POPDA men's volleyball players in East Oku which include: Education and Culture Office, PBVSI administrators, coaches, players, and facilities and infrastructures that support the program of coaching the achievements of POPDA men's volleyball East OKU .

The data collection techniques in this study are interviews conducted to obtain in-depth information about Input, Activities, Output, Outcome and Impact coaching (Arisman \& Agun Guntara, 2021).

\section{RESULTS}

Analysis results Based on input variables obtain a percentage of $68.99 \%$ which can be interpreted Good, Activities variables get a percentage of $66.77 \%$ that can be interpreted well, then the Variable Output obtains a percentage of $46.96 \%$ that can be interpreted enough, variable Outcome gets a percentage of $53.91 \%$ that can be interpreted enough and impact variable gets a percentage of $51.30 \%$ which can be interpreted enough. 
Variable Input, with sub variable managers / managers obtain a percentage of 65.91 that can be interpreted well, the trainer recruitment obtains a percentage of $90.43 \%$ which can be interpreted very well, the player's acceptance obtains a percentage of 78.04 which can be interpreted well, while the fund obtains a percentage of $51.30 \%$ which can be interpreted as sufficient and infrastructure facilities obtain a percentage of $40.87 \%$ which can be interpreted enough.

Variable activities with sub variable program implementation obtained a percentage of $78.51 \%$ which can be interpreted well, supervision of the implementation of the program obtained a percentage of $76.09 \%$ which can be interpreted well, coordination obtained a percentage of $59.13 \%$ which can be interpreted fairly, and the welfare of coaches and players obtained a percentage of $44.13 \%$ which can be interpreted fairly. Analysis of the results of the overall output variables of the study volleyball achievements POPDA East OKU District. As well as a questionnaire that aims to obtain a percentage of Input, Activities, Output, Outcome and Impact of the development of volleyball performance POPDA East OKU district and observations made by observation and recording and checking documents during research activities.

The analysis of the development of achievement volleyball POPDA East OKU obtain the average percentage of the $46,96 \%$ which can be interpreted quite. In the analysis of the results of the variable outcome overall research analysis of development of achievement volleyball POPDA East OKU obtain the average percentage of the 53,91\% which can be interpreted quite. The overall results of the percentage of variable logic on the analysis of the development of achievement volleyball POPDA East OKU is 57,59\% with enough category.

\section{CONCLUSIONS AND SUGGESTIONS}

Based on the results of data analysis and the discussion generated some conclusions as follows:

Input variables included in the category enough, although there is a gap between Sub variable include : (1) the Management of the activities of the 
POPDA East OKU good enough, the Office of u.s. network and culture, along with PENGKAB PBVSI already have a schedule for the preparation of the implementation of the POPDA each period.(2) a Coach who is assigned to train a team of volleyball POPDA East OKU is a coach who has the experience and have a coaching certificate basic level of regional and national as well as still actively foster or train in the club or school. (3) recruitment System a good enough player, to become a volleyball player POPDA East OKU District, players must follow the stages of selection such as physical tests that include: height, weight, power jump, agility, flexibility, and durability, techniques include: basic techniques, mastering the game and mentally covered: Discipline, responsibility and fighting spirit. (4) The funding for the development of volleyball achievements of POPDA East OKU Regency is actually very lacking, but the coach prepares so as to fulfill the coaching by finding a source of funds other than the budget of the education office. (5) Facilities and Infrastructure in the category of sufficient in the sense of utilizing existing facilities - infrastructure even though it does not have a indoor court or sports hall for volleyball, but the volleyball court in east OKU district either belongs to PBVSI, school or village owned, the field is suitable for training (Maretno \& Arisman, 2020).

Variable Activities are sufficient: (1) The implementation of the training program is good, already has a clear training program and the exercise runs according to the training program prepared by the trainer. (2) Supervision of the training program is quite good, can be seen by the monitoring team that provides evaluation in the stages of training. (3) Coordination between the Education and Culture Office and PBVSI administrators, coaches and volleyball players of POPDA East OKU Regency should be improved or should be more intensive for the advancement of coaching POPDA volleyball achievements for the following years, not only when going to POPDA activities only, but there must be coordination for coaching from an early age. (4) The welfare of POPDA coaches and volleyball players of East OKU Regency needs to be improved in order to be 
better and more feasible, so that players are more motivated and coaches can more focused in running the training program so that the results are more maximally in accordance with the target. more focused in running the training program so that the results are more maximally in accordance with the target.

Variable Output is sufficient, The success of the volleyball achievement coaching system East OKU district needs to be improved to be better, although the results of the research variable output in the category is sufficient, but for better achievement improvement there must be a programmatic, planned, and structured POPDA volleyball coaching gradually from elementary to high school level. Variable Outcome is sufficient, The benefits of coaching the achievements of volleyball POPDA East OKU district from the results of the study entered the category is sufficient but not yet in accordance with the target, can be seen from the acquisition of each POPDA activity medals from 2012, 2014 and last 2016 can not obtain gold medals.

Variable impact is sufficient, Coaching the achievements of volleyball POPDA East OKU district can affect the strength of the volleyball team East OKU championship-higher championships, such as: POPWIL, POPNAS, PORPROV or PRAPON. But at the moment there is no big influence because there are still few POPDA volleyball players who participated in the higher championships.

Based on the results of the study analysis of the development of volleyball achievements POPDA East OKU district and the conclusions that have been presented above, then researchers suggest improving the coaching of volleyball achievements POPDA East OKU District. The suggestions and recommendations are as follows: (1) The need to procure tests of physical components, anthropometry and psycho test in player selection. (2) The need for procurement of psycho test component tests and physical selection of trainers. (3) The need to increase the procurement of training facilities, especially special sports halls for volleyball because East OKU does not yet have a sports hall for sports games, 
especially volleyball. (4) The need to budget funds for the procurement of training equipment and also for the operational coaching of volleyball achievements, especially POPDA championships. (5) The need for regular consumption for coaches, assistant coaches, and athletes, according to the nutrition they need. Because so far they only get the consumption of extra pudding, which may not be suitable nutrition (Pratiwi \& Anggara, 2021). They've also been eating at home. which we do not know what they eat, whether the food they eat is nutritious or not. (6) The need for the procurement of dormitories, so that they can focus more on training, and the risk of travel during training is smaller. (7) The need to procure operational vehicles for athletes, because there are still many athletes who go to the training ground and school to bring their own vehicles. (8) Awarding awards such as school scholarships for outstanding volleyball players. (9) Awarding awards or rewards to coaches and athletes who have excelled.

\section{REFERENCES}

Ardo Okilanda, Firmansyah Dlis, Hidayat Humaid, D. D. P. (2020). Jurnal Educatio FKIP UNMA. Ejournal.Unma.Ac.Id, 6(2), 548-560. https://doi.org/10.31949/educatio.v6i2.594

Arisman, A., \& Agun Guntara, R. (2021). The Research Of Students' Motor Ability In Archery Extracurricular. Jurnal Maenpo: Jurnal Pendidikan Jasmani Kesehatan Dan Rekreasi, 11(1), 13. https://doi.org/10.35194/jm.v11i1.1216

Arisman, A., \& Noviarini, T. (2021). Tabata Workout dalam Meningkatkan Kebugaran Atlet Panahan. Halaman Olahraga Nusantara (Jurnal Ilmu Keolahragaan), 4(1), 12-22.

Kellogg, Will Keith Foundation. (2004). Logic models Development Guide . Michigan

Komaruddin .(2001). Manjemen Sumber Daya Manusia. Jakarta: Bumi Aksara

Lutan, Rusli (2013). Pedoman Perancangan Pembinaan Olahraga. PT Remaja Rosdakarya. Bandung.

Maretno, M., \& Arisman, A. (2020). Ladder Drill dalam Meningkatkan Kelincahan Atlet Bola Voli. Jurnal Muara Olahraga, 3(1), 1-20.

Mutohir, Toho Cholik dan Maksum, Ali (2007) Sport Development Indeks. Jakarta, PT. Indeks 


\section{OLATRAGA}

Jendral A. Yani Street Lorong Gotong Royong 9/10 U1u Palembang South Sumatera

\section{Accredited}

email jurnal: jurnalhon@univpgri-palembang.ac.id

Okilanda, A. (2017). Analisis Pembelajaran Gerak Keterampilan ....( Ardo Okilanda). 7, 31-41.

Okilanda, A., Arisman, A., Lestari, H., Lanos, M. E. C., Fajar, M., Putri, S. A. R., \& Sugarwanto, S. (2018). Sosialisasi Petanque Sebagai Olahraga Masa Kini. Jurnal Bagimu Negeri, 2(1), 69-76. https://doi.org/10.26638/jbn.638.8651

Okilanda, A., Dlis, F., Humaid, H., Putra, D. D., Arisman, A., \& Muslimin, M. (2021). Defense Warm-Up Exercise Material for 13-Age Athlete Using Video Technology in Covid-19 Era. International Journal of Human Movement and Sports Sciences, 9(4), 629-634. https://doi.org/10.13189/saj.2021.090404

Pratiwi, E., \& Anggara, N. (2021). Pengembangan Model Passing Bawah Bolavoli Pada Atlet Pemula Universitas Islam Kalimantan MAB Banjarmasin. Halaman Olahraga Nusantara (Jurnal Ilmu Keolahragaan), 4(1), 23-37. https://doi.org/dx.doi.org/10.31851/hon.v4i1.5106

Putra, D. D., Okilanda, A., Arisman, A., Lanos, M. E. C., Putri, S. A. R., Fajar, M., Lestari, H., \& Wanto, S. (2020). Kupas Tuntas Penelitian Pengembangan Model Borg \& Gall. Wahana Dedikasi: Jurnal PkM Ilmu Kependidikan, 3(1), 46. https://doi.org/10.31851/dedikasi.v3i1.5340

Taufik, M. S., Solahuddin, S., Arisman, A., Ridlo, A. F., \& Iskandar, T. (2021). Improve Learning Outcomes of Basketball Lay Up Shoot in Junior High School. COMPETITOR: Jurnal Pendidikan Kepelatihan Olahraga, 13(2), 154. https://doi.org/10.26858/cjpko.v13i2.19412

Wiradi (2009). Makna dan Pengertian analisis, Jakarta : Aneahira 